\title{
Acute Coronary Syndrome Patients Admitted to Coronary Care Unit: An In-Hospital Outcome at King Abdulaziz University Hospital
}

\author{
Layth Mimish, FACC, FRCPC, and Mohamed Radwan, MRCP, MSC \\ Department of Medicine, Faculty of Medicine, \\ King Abdulaziz University, Jeddah, Saudi Arabia \\ layth_mimish@hotmail.com
}

\begin{abstract}
The primary objective of this observational study is to compare clinical data and short-term outcome of patients admitted with acute coronary syndromes to coronary care unit in King Abdulaziz University Hospital over 1 year period, with patients enrolled in a multinational registry. The study cohort consisted of 399 patients hospitalized in King Abdulaziz University Hospital and 4,445 patients from the Global Registry of Acute Coronary Events. Average age of patients in King Abdulaziz University Hospital was nearly a decade younger (56 vs. 66 years), with male predominance ( $75 \%$ vs. $69 \%$ ). Clinical presentation and management strategies were nearly the same, but in patients with ST elevation myocardial infarction, thrombolysis rather than primary percutaneous intervention was the main strategy in our group. In-hospital mortality rates were less in King Abdulaziz University Hospital patients ( $3 \%$ vs. $3.8 \%$ ). This difference is probably related to smaller sample size, and late presentation. Future studies with larger sample size should explore the effects of differences in patient characteristics and treatment practices with long-term prognosis.
\end{abstract}

Keywords: Acute coronary syndromes, Clinical presentation, Management strategies, Mortality rates.

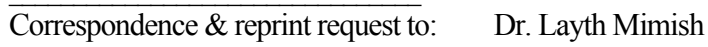
P.O. Box 4342, Jeddah 21491
}

Accepted for publication: 31 December 2013. Received: 06 October 2013. 


\section{Introduction}

In a rapidly developing field, management of patients assessments admitted with acute coronary syndromes (ACS) is required. This context plans and compares short term outcome of patients admitted to coronary care unit (CCU) in King Abdulaziz University Hospital (KAUH) to a large multi-national registry.

The primary objectives of this observational study are to compare the clinical data from our patients cohort; to assess the presence of significant difference in short-term outcomes compared to the Global Registry of Acute Coronary Events (GRACE registry) ${ }^{[1,2]}$, and whether this would alter our practice in management of ACS.

\section{Methods}

This retrospective study included all patients admitted with ACS to $\mathrm{CCU}$ in KAUH over one year starting from $1^{\text {st }}$ of June 2008 to $31^{\text {st }}$ of May 2009. GRACE is the largest multinational prospective registry designed to reflect an unselected population of patients hospitalized with ACS. In total, 123 hospitals located in 14 countries in North and South America, Europe, Australia, and New Zealand contributed data to this registry from 1999 through 2007. For the present analyses, contemporaneous individual patient data of patients with $\mathrm{ACS}^{[1,3]}$ was used.

All patients with a clinical history of ACS with $\geq 1$ of the following were included in the retrospective study samples: Electrocardiographic changes consistent with ACS, serial increases in cardiac biomarkers of necrosis, or documented coronary artery disease. Patients were diagnosed with ST-segment elevation myocardial infarction (STEMI), non-ST-segment elevation myocardial infarction (NSTEMI), or unstable angina pectoris using standardized criteria based on clinical presentation, electrocardiographic findings, and cardiac biomarkers ${ }^{[4,5]}$.

The diagnosis of ACS and definitions of key study variables and clinical complications were similar and based on the American College of Cardiology key data elements ${ }^{[6]}$. 
In the GRACE registry, patients with STEMI and patients with left bundle branch block were combined in 1 category (STEMI), and patients with NSTEMI and those with unstable angina pectoris were combined in another category (NSTE-ACS).

Analysis of data was done using STATISTICA software package.

\section{Results}

Our group consisted of 399 patients with confirmed diagnosis of ACS. Mean age was 56 years (Fig. 1) with $50 \%<55$ yr. and $10 \%>$ 75 yr. $75 \%$ of patients were males (Fig. 2). 36\% of our patients presented with STEMI and 64\% presented with NSTEACS (Fig. 3).

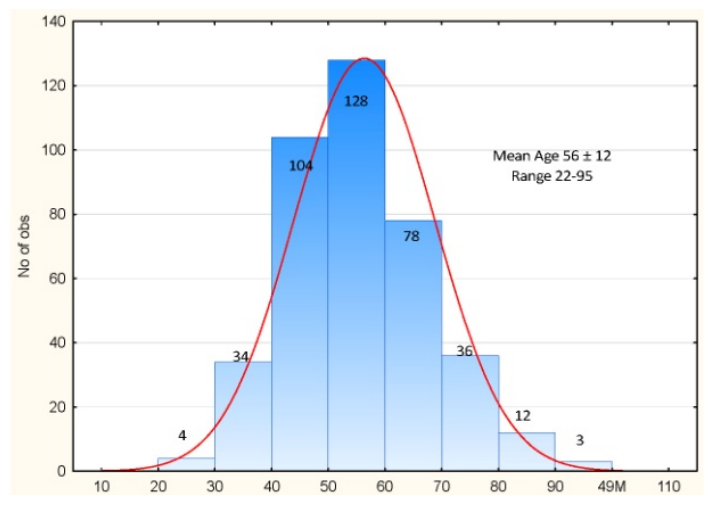

Fig. 1. Age distribution.

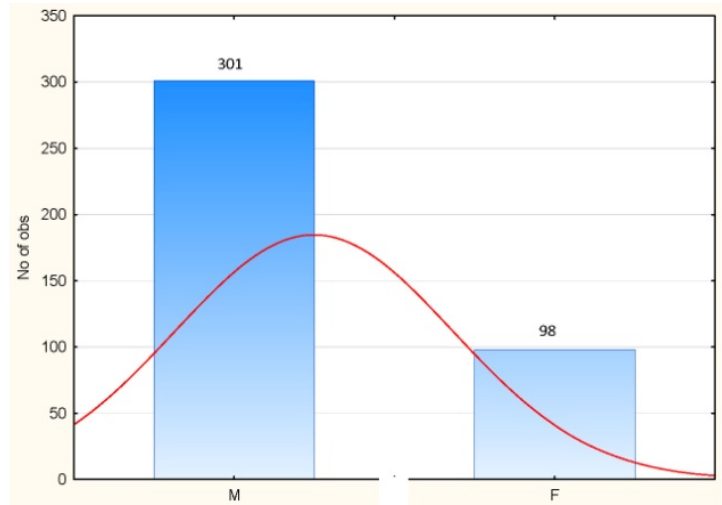

Fig. 2. Histogram of gender. 


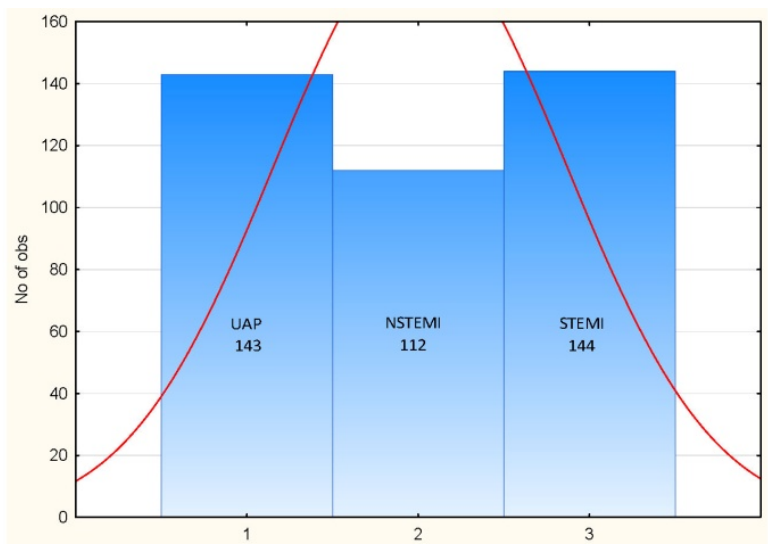

Fig. 3. Discharge diagnosis.

Presentation with NSTEACS occurred more frequently in females than in males (74\% vs. $61 \%$, Fig. 4$)$.

236 patients underwent coronary angiography (59\%). Of those $22 \%$ continued on medical treatment, $52 \%$ underwent percutaneous intervention (PCI), while 26\% were referred for coronary artery bypass grafting (CABG, Fig. 5).

Angiography was done more frequently in males than in females (61.4\% vs. 52.6\%, Fig. 6).
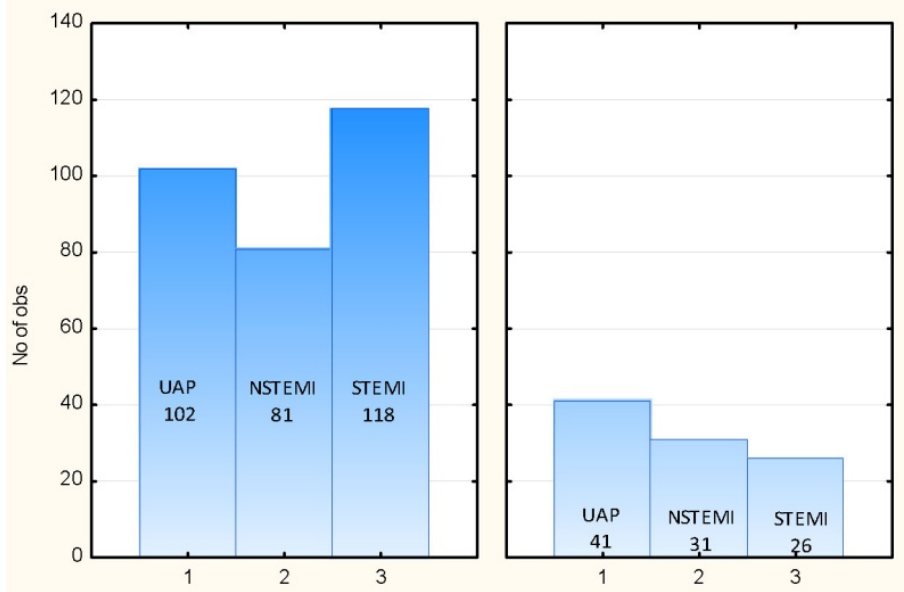

Fig. 4. Discharge diagnosis categorized by gender. 


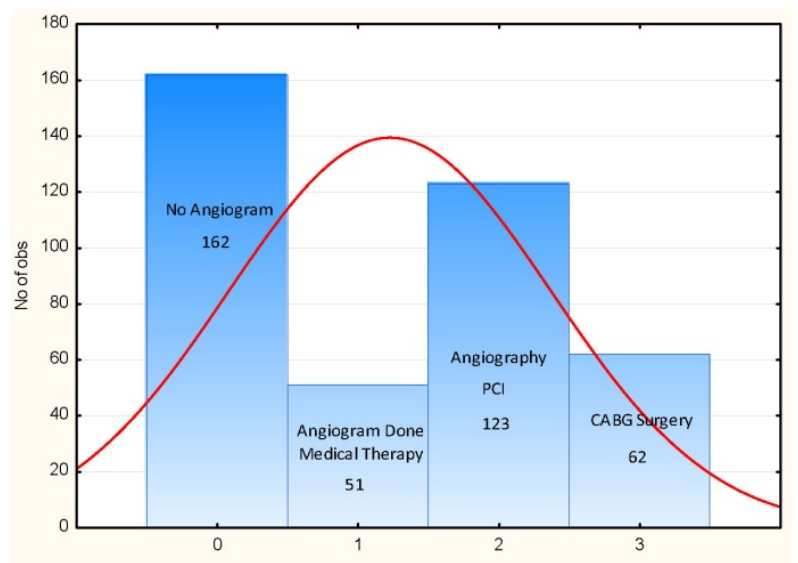

Fig. 5. Histogram of coronary angiography.

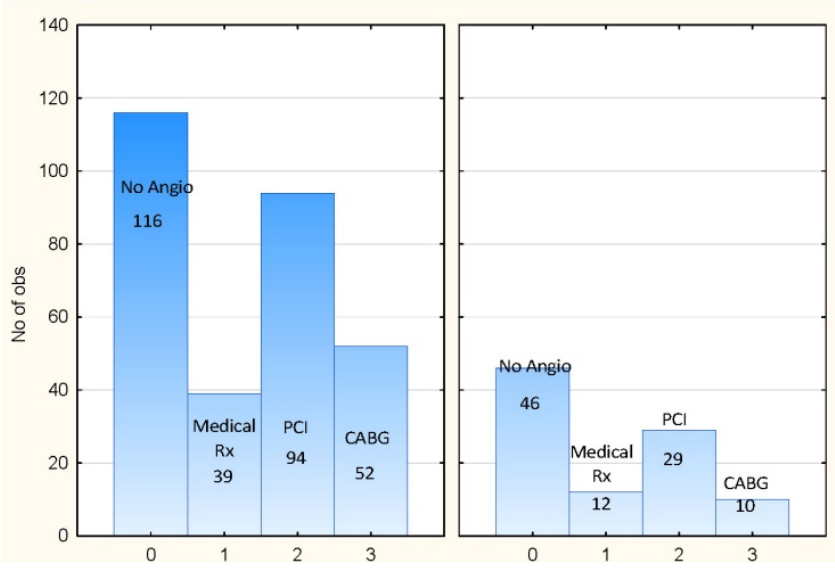

Fig. 6. Coronary angiography categorized by gender.

In patients with STEMI cardiac catheterization was performed in $63 \%$ of patients. While patients admitted with NSTE-ACS, $57 \%$ had coronary angiography (Fig. 7).

387 patients were discharged home, 4 were transferred to other centers, 3 were discharged against medical advice and 5 died (4 females, and 1 male) (Fig. 8, 9). During the same period of study, 36 patients with ACS were admitted to ICU, 8 of them died in-hospital, giving mortality rate of $3 \%$ (Fig 10 ). 


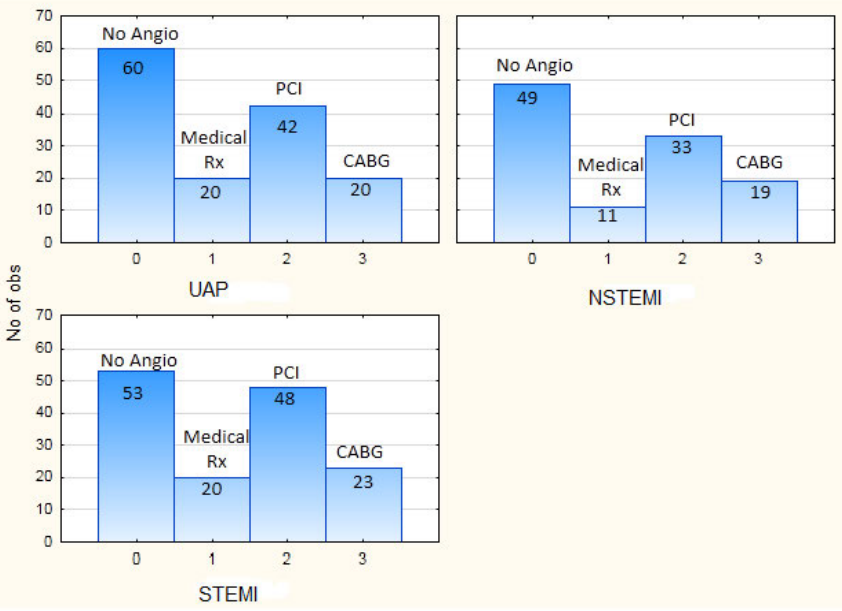

Fig. 7. Coronary angiography categorized by discharge diagnosis.

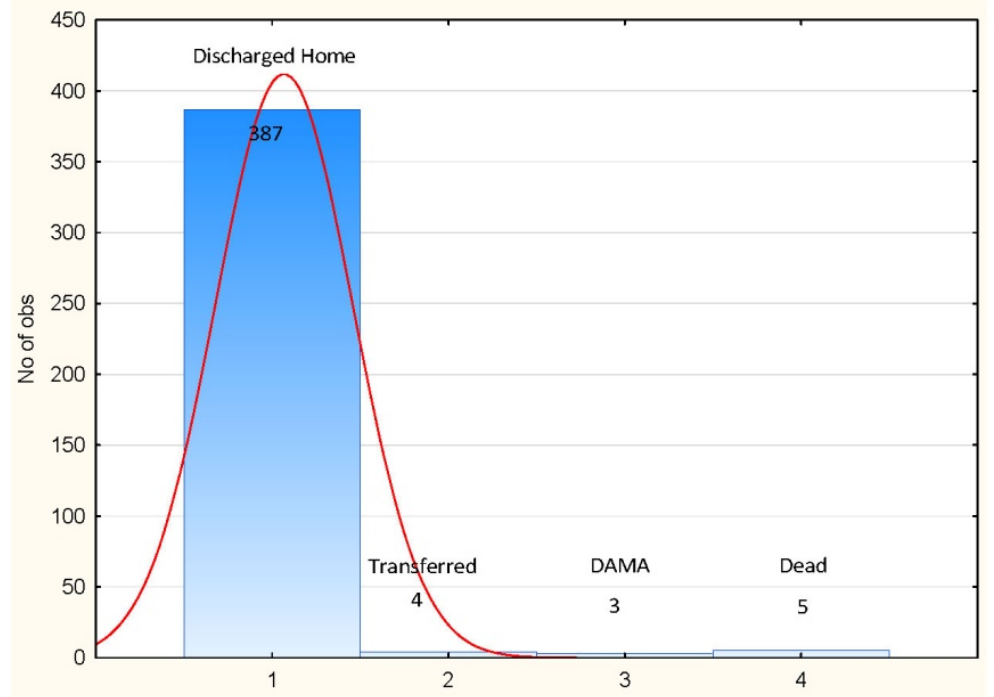

Fig. 8. Final status of 339 patients. 

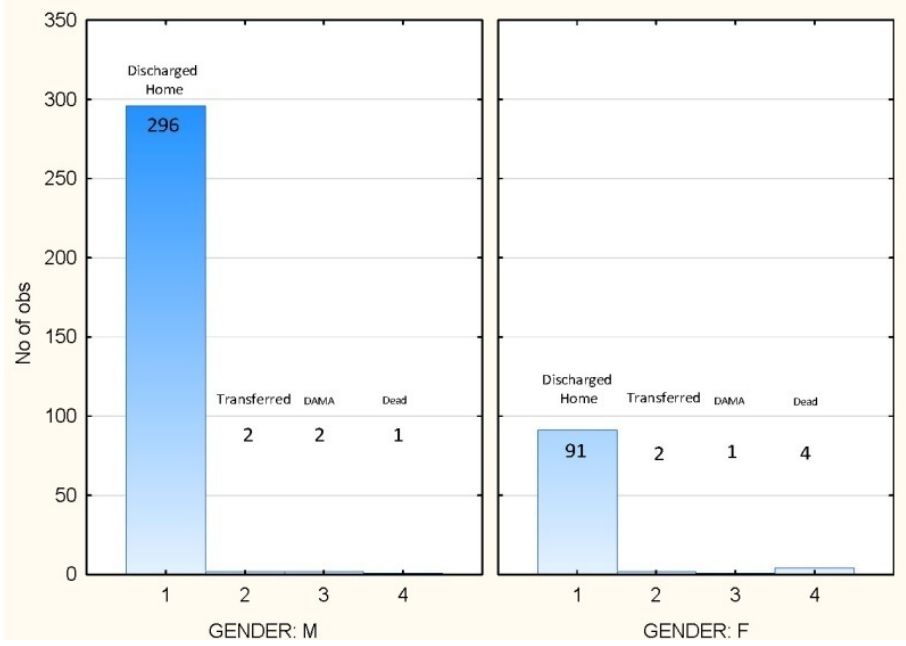

Fig. 9. Final status categorized by gender.

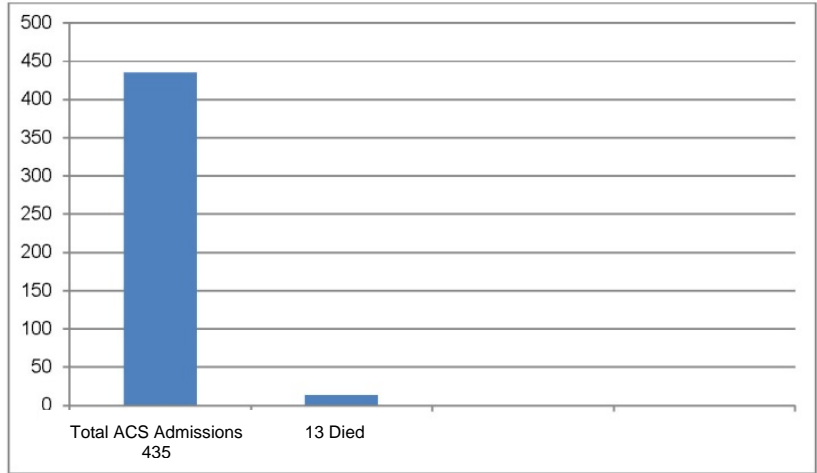

Fig. 10. Total mortality of ACS admissions.

\section{Discussion}

The present study is intended to compare the characteristics, management practices, and hospital outcomes of patients with ACS admitted to $\mathrm{CCU}$ in $\mathrm{KAUH}$ to a large multinational and predominantly western population hospitalized with ACS.

Our study shows that average age of patients in KAUH was nearly a decade younger than in GRACE (56 vs. 66 years). The proportion of patients $<55$ years old was approximately 2 times 
of that in GRACE, whereas the proportion of patients $>75$ years old in KAUH was $<1 / 2$ that of GRACE (Table 1). Patients in KAUH were more likely to be men (75\% vs. $69 \%$ (Table 1$)$ ).

Table 1. Baseline characteristics of patients hospitalized with acute coronary syndrome.

\begin{tabular}{l|c|c|c}
\hline \multicolumn{1}{c|}{ Characteristic } & \multicolumn{3}{c}{ All ACS } \\
\hline & GRACE & KAUH & \multirow{2}{*}{$\boldsymbol{p}$ Value } \\
\hline Age (years), mean \pm SD & N = 4445 & N = 399 & $<0.01$ \\
\hline Age (years) & $65 \pm 13$ & $56 \pm 12$ & $<0.01$ \\
\hline$<55$ & & & \\
\hline$>75$ & $1039(23 \%)$ & $200(50 \%)$ & \\
\hline Men & $1209(27 \%)$ & $40(10 \%)$ & \\
\hline
\end{tabular}

Previous work has suggested that patients with ACS in the Gulf region are more likely to develop ACS at a younger age ${ }^{[2,7,8]}$; similar findings were observed in the present study. This striking difference might have resulted from differences in the coronary risk factor profile between the 2 cohorts leading to earlier development of ACS, or acceleration of underlying coronary atherosclerosis in subjects in Saudi Arabia, with more than 50\% having diabetes, dyslipidemia, or being smokers.

The distribution of patients between STEMI and NSTEACS is nearly the same in both KAUH and GRACE (Table 2). The degree of intervention in NSTEACS is comparable (Table 2). In patients with STEMI, although primary PCI was the main reperfusion therapy in GRACE, the overall percentage of patients who underwent coronary angiography was nearly the same in both GRACE and KAUH (Table 2).

Table 2. Presentation of patients and degree of intervention.

\begin{tabular}{l|c|c|c|c|c}
\hline & \multicolumn{2}{|c|}{ STEMI } & \multicolumn{2}{c|}{ NSTEACS } & \multirow{2}{*}{ Value } \\
\cline { 2 - 6 } & GRACE & KAUH & GRACE & KAUH & \\
\hline No. of Patients & $1504(34 \%)$ & $144(36 \%)$ & $2941(66 \%)$ & $255(64 \%)$ & $<0.01$ \\
\hline No. of Angiography & $932(62 \%)$ & $91(63 \%)$ & $1747(59.4 \%)$ & $145(57 \%)$ & $<0.01$ \\
\hline
\end{tabular}

In-hospital mortality rates were $1 \mathrm{ess}$ in KAUH than those in GRACE $(3 \%$ compared to $3.8 \%$ in GRACE, $P$ value $<0.01)$. This difference is probably related to smaller sample size in $\mathrm{KAUH}$ 
patients, and late presentation due to relative deficiency of prehospital care.

Previously published studies have shown that women were more likely to have higher rates of co-morbidities were less likely to receive evidence-based procedures and medications, and had higher rates of adverse outcomes compared to men ${ }^{[7,14]}$. Women in our study were less likely to have coronary angiography than men (Fig. 6) and had a significantly higher adjusted mortality risk (Fig. 9).

Regional variations in ACS management practices throughout the world have been previously reported ${ }^{[9-11]}$ and have been partly explained by differences in health care models and rapidity of adopting evidence-based medicine guidelines. Furthermore, regional and inter-country differences in short-term clinical outcomes of patients hospitalized with ACS have been previously observed ${ }^{[10-13]}$.

In conclusion, despite difference in age profile of our patients and GRACE population, percentage of modes of presentation and management strategies were comparable apart from percentage of patients with STEMI undergoing primary PCI. This highlights the importance of overcoming logistic difficulties in performing primary PCI in our hospital.

Further study is needed to compare Arab vs. non-Arab populations, relative prevalence of different risk factors and their impact on outcome.

\section{References}

[1] GRACE Investigators. Rationale and design of the GRACE (Global Registry of Acute Coronary Events) Project: a multinational registry of patients hospitalized with acute coronary syndromes. Am Heart J 2001; 141(2): 190-199.

[2] Zubaid M, Rashed WA, Almahmeed W, Al-Lawati J, Sulaiman K, AlMotarreb A, Amin H, Al Suwaidi J, Alhabib K. Management and outcomes of Middle Eastern patients admitted with acute coronary syndromes in the Gulf Registry of Acute Coronary Events (Gulf RACE). Acta Cardiol 2009; 64(4): 439-446.

[3] Granger CB. Strategies of patient care in acute coronary syndromes: rationale for the Global Registry of Acute Coronary Events (GRACE) registry. Am J Cardiol 2000; 86(12B): 4M-9M. 
[4] Alsheikh-Ali AA, Al-Mallah MH, Al-Mahmeed W, Albustani N, Al Suwaidi J, Sulaiman K, Zubaid M; Gulf RACE Investigators. Heart failure in patients hospitalized with acute coronary syndromes: observations from the Gulf Registry of Acute Coronary Events (Gulf RACE). Eur J Heart Fail 2009; 11(12): 1135-1142.

[5] Steg PG, Goldberg RJ, Gore JM, Fox KA, Eagle KA, Flather MD, Sadiq I, Kasper R, Rushton-Mellor SK,Anderson FA; GRACE Investigators. Baseline characteristics, management practices, and in-hospital outcomes of patients hospitalized with acute coronary syndromes in the Global Registry of Acute Coronary Events (GRACE). Am J Cardiol 2002; 90(4): 358-363.

[6] Cannon CP, Battler A, Brindis RG, Cox JL, Ellis SG, Every NR, Flaherty JT, Harrington RA, Krumholz HM,Simoons ML, Van De Werf FJ, Weintraub WS, Mitchell KR, Morrisson SL, Brindis RG, Anderson HV,Cannom DS, Chitwood WR, Cigarroa JE, Collins-Nakai RL, Ellis SG, Gibbons RJ, Grover FL, Heidenreich PA, Khandheria BK, Knoebel SB, Krumholz HL, Malenka DJ, Mark DB, Mckay CR, Passamani ER, Radford MJ, Riner RN, Schwartz JB, Shaw RE, Shemin RJ, Van Fossen DB, Verrier ED, Watkins MW, Phoubandith DR, Furnelli T. American College of Cardiology key data elements and definitions for measuring the clinical management and outcomes of patients with acute coronary syndromes. A report of the American College of Cardiology Task Force on Clinical Data Standards (Acute Coronary Syndromes Writing Committee). J Am Coll Cardiol 2001; 38(7): 2114-2130.

[7] El-Menyar A, Zubaid M, Rashed W, Almahmeed W, Al-Lawati J, Sulaiman K, Al-Motarreb A, Amin H, Al Suwaidi J. Comparison of men and women with acute coronary syndrome in six Middle Eastern countries. Am J Cardiol 2009; 104(8): 1018-1022.

[8] Zubaid M, Rashed WA, Saad H, Attiya A, Al-Banat BA, Ridha M, Al-Kandari MH, Baidas G, Al-Hamdan R, Zubair S, Thalib L. Kuwait Acute Coronary Syndromes Registry: baseline characteristics, man- agement practices and in-hospital outcomes of patients hospitalized with acute coronary syndromes in Kuwait. Med Princ Pract 2007; 16(6): 407-412.

[9] Hasdai D, Behar S, Wallentin L, Danchin N, Gitt AK, Boersma E, Fioretti PM, Simoons ML, Battler A. A prospective survey of the characteristics, treatments and outcomes of patients with acute coronary syndromes in Europe and the Mediterranean basin; the Euro Heart Survey of Acute Coronary Syndromes (Euro Heart Survey ACS). Eur Heart J 2002; 23(15): 1190-1201.

[10] Thalib L, Zubaid M, Rashed W, Almahmeed W, Al-Lawati J, Sulaiman K, AlMotarreb A, Amin H, Al Suwaidi J, Alhabib KF. Regional variability in hospital mortality in patients hospitalized with ST-segment elevation myocardial infarction: findings from the Gulf Registry of Acute Coronary Events. Med Princ Pract 2011; 20(3): 225-230.

[11] Fox KA, Goodman SG, Klein W, Brieger D, Steg PG, Dabbous O, Avezum A. Management of acute coronary syndromes. Variations in practice and outcome; findings from the Global Registry of Acute Coronary Events (GRACE). Eur Heart $J$ 2002; 23(15): 1177-1189.

[12] Kramer JM, Newby LK, Chang WC, Simes RJ, Van de Werf F, Granger CB, Lee KL, White HD, Piegas LS, Topol EJ, Califf RM, Armstrong PW. International 
variation in the use of evidence-based medicines for acute coronary syndromes. Eur Heart J 2003; 24(23): 2133-2141.

[13] Van de Werf F, Topol EJ, Lee KL, Woodlief LH, Granger CB, Armstrong PW, Barbash GI, Hampton JR, Guerci A, Simes RJ, Ross AM, Califf RM. Variations in patient management and outcomes for acute myocardial infarction in the United States and other countries. Results from the GUSTO trial. Global Utilization of Streptokinase and Tissue Plasminogen Activator for Occluded Coronary Arteries. JAMA 1995; 273(20): 1586-1591.

[14] Dey S, Flather MD, Devlin G, Brieger D, Gurfinkel EP, Steg PG, Fitzgerald G, Jackson EA, Eagle KA. Sex-related differences in the presentation, treatment and outcomes among patients with acute coronary syndromes: the Global Registry of Acute Coronary Events. Heart 2009; 95(1): 20-26. 


\section{النتائج الإكلينيكية لعلاج مرضى متلازمة نقص التروية القلبية الحاد أثناء التتويم بالعناية المركزة بمسنتفى جامعة الملك عبدالعزبز - جدة}

\section{ليث ميمش، ومحمد رضوان}
قسم الباطنة، كلية الطب، جامعة الكلك عبد العزيز جدة ـ المملكة العربية السعودية السية

الهستخص. إن الهفف الأساسي من هذه الدراسة الرصدية هو مقارنة الييانات السريرية وننائجها على المدى القصير من المرضى الذين ينم

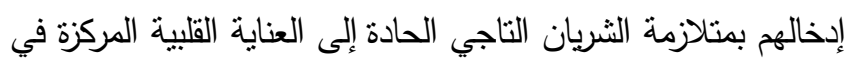
مستشفى جامعة الملك عبد العزيز على مدى سنة واحدة ، بالإضافة

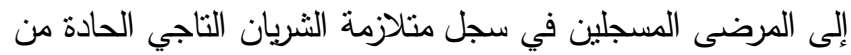
الجنسيات غير العربية المختلفة(جريس). تكونت مجموعة الدراسة من الفئ

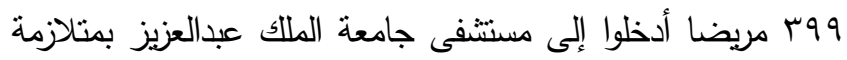

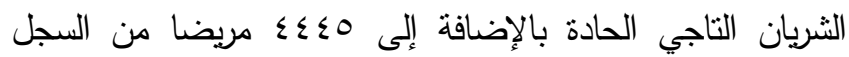

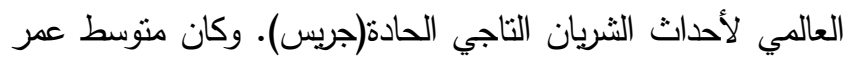

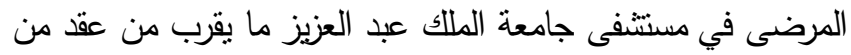

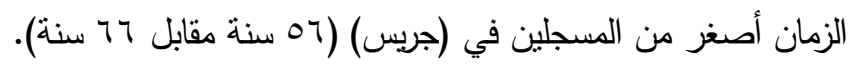

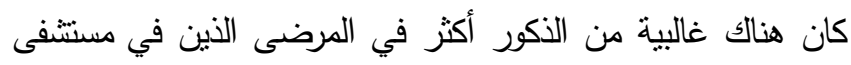

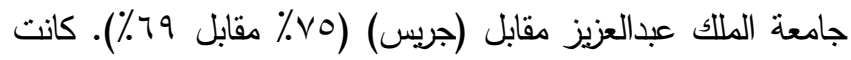

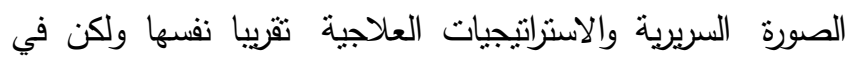
المرضى الذين بعانون من احتثاء كامل، كان التخل بالقنطرة القليبة العلاجية الأولية هي الاستراتيجية الأساسية في (جريس)، بينما كان النيان 
إعطاء الأدوية الحالة للخثرة هي الاستراتيجة الأساسية في مستشفى

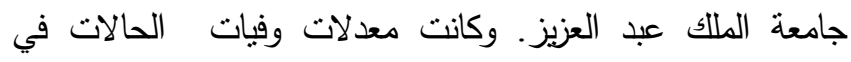

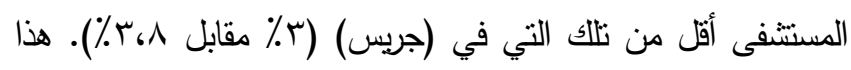

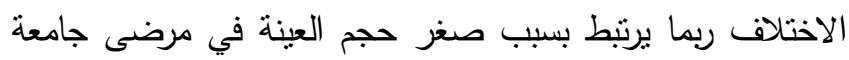

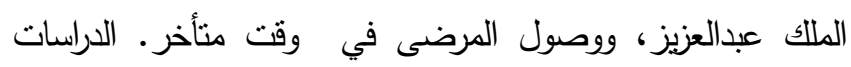

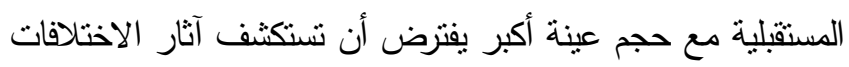
في خصائص المرضى والممارسات العلاجية على المدى الطويل. 